\title{
sdmimd
}

\section{Awareness of and Attitude Towards Learning of Non-English Foreign Languages Among Higher Secondary, Graduation and Post-Graduation Students in the City of Kolkata - An Empirical Study}

\author{
'Rajib Bhattacharya and ${ }^{2}$ Sharmila Maity \\ 'Budge Budge Institute of Technology, Kolkata \\ ${ }^{2}$ Sikkim Manipal University, Gangtok, Sikkim
}

\begin{abstract}
The globalisation spree among the emerging economies is enhancing the integration of the economies of the world with their own economies. India is no exception as it is evidenced by the increasing FDI flow and crossborder mergers and acquisitions not only in monetary values but also in number of countries involved. This trend can be accelerated, if the work force of our country as well as those of other nations of the world become more appreciative of each others' cultural aspects. One way to augment mutual appreciation of each others' cultures is knowledge of foreign languages, i.e., languages of different nations. This facilitates cross-cultural management and synergistic utilisation of cultural diversities. With increasing degree of globalisation, more and more countries are coming in contact with each other through trade and commercial activities. The dependence on English as the global language is thus diminishing fast. Knowledge of different national languages offers significant benefits like harnessing overseas opportunities, accessing cultural riches of immigrant communities, and reducing cultural clashes. The benefits of knowing different foreign languages include assisting in grasping another way of thinking, enhancing memory, critical thinking, and study skills. In business, communication and negotiation skills improve with knowledge in foreign languages. Students form the future of any economy. This paper aims at assessing the awareness of and attitude towards learning non-English foreign languages among higher secondary, graduation and post-graduation students, both from professional and academic streams in the city of Kolkata and suburbs. The paper also suggests ways to motivate students to learn foreign languages along with their normal course of study. This will help them to enhance their employability not only in India but also abroad. Moreover, at a macro level, the quality of human capital in India will be held in higher esteem by the global community. Prospective sectors in India e.g. social work, medicine, law, international business, community organising, foreign service, journalism, hospitality, education, etc. will be highly benefited, if the linguistic capability of the work force is enhanced by the knowledge of other foreign languages as there will be more international participation both inward and outward in these sectors. This will pave the way for accelerated integration of the Indian economy with the global economy.
\end{abstract}

Keywords: globalisation, culture, cross-cultural management, cultural diversity, foreign languages, students, employability, quality of human capital 


\section{Introduction}

Globalisation of commercial and economic activities is a world-wide trend at present. This is evidenced by the increasing foreign trade, rising FDI flow and more frequent cross-border mergers and acquisitions not only in monetary values, but also in number of countries involved.

Resources are not uniformly distributed among the nations of the world. Mutual sharing of resources for a symbiotic development of the different national economies is the central spirit of globalisation. In essence, globalisation is based on the free flow of goods \& services, capital, technology and labour between the different countries of the world. With the development of information technology, certain categories of crossborder labour mobility, mainly in the service sector is possible today without physical relocation of the staff.

However, the free flow of the four aspects as mentioned above is facilitated by prompt and effective communication. In case of cross-border situations, difference in language stands as a hurdle in the way of such free flow.

Thus, along with technical capability, significance of multi-linguistic capability cannot be over-emphasized in case of cross-border business and economic transactions. Language is an important constituent of culture. Apart from bridging the gap of linguistic differences, multilinguistic capability can catalyse mutual understanding between different cultures and reduce the possibilities of cultural clashes. Therefore, multi-linguistic capability can be a powerful tool in facilitating cross-cultural management and also in synergistic utilisation of cultural diversities.

Students of today are the work force of tomorrow. India is a country of different languages. Thus, knowledge of English as a common medium of communication is embedded within the curricular program of most educational courses in our country. Students have a feeling that knowledge of English alone would be sufficient in enhancing their employability as well as in entrepreneurship, should they opt for business as a career alternative. The importance of gaining proficiency in non-English foreign languages as an enhancer of employability in the current business scenario is still not known to students, as it is evidenced by the number of admissions in foreign language courses compared to those in spoken English courses. As an ancillary benefit, knowing different foreign languages, include assisting in grasping another way of thinking, enhancing memory, critical thinking, and study skills.

Thus, considering the present trend in the globalised business scenario, increasing the employability of our future work force and enhancing the quality of our future human capital, multi-linguistic proficiency is an absolute must.

\section{Motivation for the Study}

It has been observed that with the increasing globalisation process throughout the world, multi-linguistic proficiency has opened up some new career opportunities besides enhancing employability for job aspirants. This is evidenced by comparatively higher compensation packages and better career opportunities offered by some MNCs operating in India to their employees and/or job aspirants having multi-linguistic proficiency in non-English foreign languages. This is more prominent for those MNCs who are based in non-English speaking countries and follow ethnocentric style of management. Cross-border mobility is also enhanced by knowledge of foreign languages which also raises opportunities for overseas trade. A lucrative self-employment opportunity of acting as interpreters is fast increasing these days, when foreign delegates from non-English speaking countries visit India for different purposes and interpreters are needed to facilitate communication. Demand for trained teachers in foreign languages is also rising in the institutes conducting courses on foreign languages. These facts motivated to carry out the study as a pilot study in Kolkata and suburbs.

\section{Literature Survey}

The literature survey for this paper has been done with the objective of probing into the views of scholars on the role of multi-linguistic proficiency in facilitating 
cross-cultural management, synergistic utilisation of cultural diversities, enhancing career opportunities, and overall enhancement of quality in human capital. Works of scholars like Ansari (1995), Gupta (1998), Hamdorf (2006), Norales (2006), Dogra (2009), Bhattacharya (2010, 2012), De Bono and Heijden. (2011), Edwards (2011), Madhavan (2011) and Maude (2011) have been referred to in this paper. Moreover, reports of NEA Research (2007) and AACSB International (2011) have also been referred.

\section{Objective of the Study}

The objective of this paper is two fold. Firstly, this paper aims at assessing the awareness and attitude towards learning non-English foreign languages among higher secondary, graduation and post-graduation students, both from professional and academic streams in the city of Kolkata and suburbs. Secondly, this paper also suggests ways to motivate students to learn foreign languages along with their normal course of study.

\section{The Methodology Adopted for the Study}

\subsection{Identification of the Respondents and the Variables}

A preliminary survey was conducted within the city limits of Kolkata and suburbs through informal discussion, on a few students of higher secondary and different streams of graduation and post-graduation courses regarding the awareness and attitude towards learning any non-English foreign language along with their current academic pursuits.

Based on the inputs received from the survey, certain attributes were identified which could be determinants of awareness and attitude of students towards non-English foreign languages, i.e.,

i. their career objectives

ii. their gender

iii. their current academic pursuit and

iv. their reliance on English as a sufficient second language to enhance career opportunities
Four prominent areas of application of multi-linguistic proficiency were also identified, i.e.,

i. enhancement of employability in MNCs

ii. augmenting overseas business opportunities

iii. career opportunity as a language instructor in training institutes conducting foreign language courses and

iv. self-employment opportunity as interpreters

These four attributes and four potential areas application constitute the parameters of this study.

\subsection{The Population}

The present competitive scenario in the job market compels the students to enhance their employability right from their higher secondary stage. Based on this fact and on the profile of the students taking admission in various institutions conducting courses on foreign languages, the population for this study has been determined to consist of students of higher secondary, graduation \& postgraduation courses, both academic and professional.

\subsection{Area of the Study}

The city of Kolkata in West Bengal and suburbs has been chosen for the study. In Kolkata, there are several institutions conducting higher secondary and graduation and post-graduation courses in various streams, both academic and professional.

\subsection{The Questionnaire}

The questionnaire has been developed on the basis of the eight parameters mentioned above. The questionnaire consisted of objective type closed ended fixed choice questions. The questionnaire is contained in the Annexure.

\subsection{Sampling Methodology}

Institutions and coaching centers were visited on judgment basis all over the city of Kolkata and suburbs. Students were approached outside the college premises after college hours. They were informed about the study and its objectives. Willing students were asked the questions from the questionnaire and their verbal responses were noted by the enumerators. Some students chose to fill up the questionnaire themselves and they were allowed to do so. Neither did they allow their contact details to be taken nor did they disclose their identities. 


\subsubsection{The Sample}

The sample was collected from Kolkata as well as from suburbs covering students of both genders. The sample was collected so as to cover higher secondary, graduation and post graduation courses, both from academic and professional streams. A total of 120 samples were collected of which 73 were male and 47 were female students. The sample consists of 17 higher secondary students, 44 graduate students of academic streams, 17 graduate students of professional streams, 22 post-graduate students of academic streams and 20 post-graduate students of professional streams.

\subsubsection{Methodology of Analysis}

Simple percentage calculations have been carried out to get an indication of the overall view of the students' awareness and attitude. To test whether such attitude and awareness are associated, such findings need subsequent test for independence of attributes. Hence, $\chi^{2}$ test has been used to test all the hypotheses. The hypotheses have been tested both at $5 \%$ as well as $1 \%$ levels of significance.

\subsubsection{Limitations of the Study}

The study for this paper is subject to certain limitations. Firstly, ensuring examinations and reluctance of the students to participate limited the size of the sample. Secondly, though there are various determinants of awareness and attitude towards learning foreign languages, only a few of them as mentioned above have been considered in this study.

\subsubsection{The Working Hypotheses}

The working hypotheses have been formulated keeping in view the identified attributes and also to test the associatedness of such attributes to guide the awareness generating program. The main research questions for the paper are:

1. whether the intention to learn foreign language is related with the career objectives of the students

2. whether the intention to learn foreign language is related with the gender of the students

3. whether the intention to learn foreign language is related with the present academic/professional pursuit of the students and
4. whether the intention to learn foreign language is related with the dependence of the students on English as a sufficient second language option to enhance career opportunities

The ancillary research questions for the paper are:

1. whether the awareness of foreign language as an enhancer of job opportunities in MNCs is related with the career objectives, gender and current academic/professional pursuit of the students

2. whether the awareness of foreign language as an enhancer of job opportunities as trainers in institutions conducting foreign language courses is related with the career objectives, gender and current academi/professional pursuit of the students

3. whether the awareness of foreign language as an enhancer of overseas business opportunities is related with the career objectives, gender and current academic/professional pursuit of the students and

4. whether the awareness of foreign language as an enhancer of self-employment opportunities as interpreters is related with the career objectives, gender and current academic/professional pursuit of the students

Accordingly, the following sixteen working hypotheses have been formulated.

Hypotheses regarding the main research question:

\begin{tabular}{ll}
\hline $1^{\text {st }}$ Hypothesis: & $\mathrm{H}_{0} 1$ : There is no association between the intention to \\
& learn foreign languages and the career objectives of the \\
& students \\
$2^{\text {nd }}$ Hypothesis: & $\mathrm{H}_{0} 2$ : There is no association between the intention to learn \\
& foreign languages and the gender of the students \\
$3^{\text {rd }}$ Hypothesis: & $\mathrm{H}_{0} 3$ : There is no association between the intention to learn \\
& foreign languages and the present academic/professional \\
& pursuit of the students \\
& $\mathrm{H}_{0} 4:$ There is no association between the intention to learn \\
& foreign languages and the dependence of the students on \\
& English as a sufficient second language option as enhancer \\
& of career opportunities
\end{tabular}

Hypotheses regarding the ancillary research question:

\begin{tabular}{ll}
\hline $5^{\text {th }}$ Hypothesis & $\mathrm{H}_{0} 5$ : There is no association between the awareness of \\
& foreign language as an enhancer of job opportunities in \\
& MNCs and the career objectives of the students \\
$6^{\text {th }}$ Hypothesis & $\begin{array}{l}\mathrm{H}_{0} 6 \text { : There is no association between the awareness of } \\
\text { foreign language as an enhancer of job opportunities in } \\
\text { MNCs and the gender of the students }\end{array}$
\end{tabular}


$7^{\text {th }}$ Hypothesis $\quad \mathrm{H}_{0} 7$ : There is no association between the awareness of foreign language as an enhancer of job opportunities in MNCs and the current academic/professional pursuit of the students

$8^{\text {th }}$ Hypothesis $\quad H_{0} 8$ : There is no association between the awareness of foreign language as an enhancer of job opportunities as trainers in institutions conducting foreign language courses and the career objectives of the students

$9^{\text {th }}$ Hypothesis $\quad \mathrm{H}_{0}$ 9: There is no association between the awareness of foreign language as an enhancer of job opportunities as trainers in institutions conducting foreign language courses and the gender of the students

$10^{\text {th }}$ Hypothesis $\quad H_{0} 10$ : There is no association between the awareness of foreign language as an enhancer of job opportunities as trainers in institutions conducting foreign language courses and the current academic/professional pursuit of the students

$11^{\text {th }}$ Hypothesis $\quad H_{0} 11$ : There is no association between the awareness of foreign language as an enhancer of overseas business opportunities and the career objectives of the students

$12^{\text {th }}$ Hypothesis $\quad H_{0} 12$ : There is no association between the awareness of foreign language as an enhancer of overseas business opportunities and the gender of the students

$13^{\text {th }}$ Hypothesis $\quad H_{0} 13$ : There is no association between the awareness of foreign language as an enhancer of overseas business opportunities and the current academic/professional pursuit of the students

14 $4^{\text {th }}$ Hypothises $\quad \mathrm{H}_{0} 14$ : There is no association between the awareness of foreign language as an enhancer of self-employment opportunity as interpreters and the career objectives of the students

$15^{\text {th }}$ Hypothesis $\quad H_{0} 15$ : There is no association between the awareness of foreign language as an enhancer of self-employment opportunity as interpreters and the gender of the students

$16^{\text {th }}$ Hypothesis $\quad H_{0} 16$ : There is no association between the awareness of foreign language as an enhancer of self-employment opportunity as interpreters and the current academic/ professional pursuit of the students

\section{Findings of the Study}

\subsection{Simple Percentage Calculations}

The number of the students vis-à-vis their answers to the questions designed according to the sixteen hypotheses stated above are appended below:

$1^{\text {st }}$ Hypothesis:

\begin{tabular}{lcccc}
\hline $\begin{array}{l}\text { Intention to } \\
\text { Learn Foreign } \\
\text { Language }\end{array}$ & \multicolumn{3}{c}{ Career Objectives } & Total \\
\cline { 2 - 4 } & Service & Business & Not Sure \\
\hline No & 9 & 8 & 2 & $19(15.83 \%)$ \\
Not Sure & 14 & 3 & 3 & $20(16.67 \%)$ \\
Yes & 46 & 26 & 9 & $81(67.50 \%)$ \\
Total & $69(57.50 \%)$ & $37(30.83 \%)$ & $14(11.67 \%)$ & 120 \\
\hline
\end{tabular}

$2^{\text {nd }}$ Hypothesis:

\begin{tabular}{|c|c|c|c|}
\hline \multirow{2}{*}{$\begin{array}{l}\text { Intention to } \\
\text { Learn Foreign } \\
\text { Language }\end{array}$} & \multicolumn{2}{|c|}{ Gender } & \multirow[t]{2}{*}{ Total } \\
\hline & Female & Male & \\
\hline No & 7 & 12 & $19(15.83 \%)$ \\
\hline Not Sure & 6 & 14 & $20(16.67 \%)$ \\
\hline Yes & 34 & 47 & $81(67.50 \%)$ \\
\hline Total & $47(39.17 \%)$ & $73(60.83 \%)$ & 120 \\
\hline
\end{tabular}

$3^{\text {rd }}$ Hypothesis:

\begin{tabular}{lcccccc}
\hline Intention & \multicolumn{5}{c}{ Present Academic / Professional Pursuit } & Total \\
\cline { 2 - 6 } $\begin{array}{l}\text { to Learn } \\
\text { Foreign } \\
\text { Language }\end{array}$ & $\begin{array}{c}\text { Higher } \\
\text { Secondary }\end{array}$ & Graduation - Graduation - & $\begin{array}{c}\text { Post- } \\
\text { Academic }\end{array}$ & $\begin{array}{c}\text { Post- } \\
\text { Professional }\end{array}$ & \\
Graduation - & $\begin{array}{c}\text { Graduation - } \\
\text { Academic }\end{array}$ & Professional \\
\hline No & 1 & 8 & 3 & 4 & 3 & $19(15.83 \%)$ \\
Not Sure & 4 & 10 & 3 & 2 & 1 & $20(16.67 \%)$ \\
Yes & 12 & 26 & 11 & 16 & 16 & $81(67.50 \%)$ \\
Total & $17(14.17 \%)$ & $44(36.67 \%)$ & $17(14.17 \%)$ & $22(18.33 \%)$ & $20(16.66 \%)$ & 120 \\
\hline
\end{tabular}

$4^{\text {th }}$ Hypothesis:

\begin{tabular}{|c|c|c|c|c|}
\hline \multirow{2}{*}{$\begin{array}{l}\text { Intention } \\
\text { to Learn } \\
\text { Foreign } \\
\text { Language }\end{array}$} & \multicolumn{3}{|c|}{$\begin{array}{c}\text { English is sufficient as } 2^{\text {nd }} \text { Language to } \\
\text { enhance career opportunities }\end{array}$} & \multirow[t]{2}{*}{ Total } \\
\hline & No & Not Sure & Yes & \\
\hline No & 4 & 3 & 12 & $19(15.83 \%)$ \\
\hline Not Sure & 3 & 8 & 9 & 20 (16.67\%) \\
\hline Yes & 24 & 17 & 40 & $81(67.50 \%)$ \\
\hline Total & 31 (25.83\%) & 28 (23.33\%) & 61 (50.84\%) & 120 \\
\hline
\end{tabular}

$5^{\text {th }}$ Hypothesis:

\begin{tabular}{lcccc}
\hline $\begin{array}{l}\text { Learning Foreign } \\
\text { Language can } \\
\text { enhance job }\end{array}$ & \multicolumn{3}{c}{ Career Objectives } & Total \\
\cline { 2 - 4 } $\begin{array}{l}\text { opportunity in } \\
\text { MNCs }\end{array}$ & Service & Business & Not Sure \\
\hline Agree & & & & \\
Disagree & 42 & 23 & 6 & $71(59.17 \%)$ \\
Not Sure & 12 & 3 & 2 & $17(14.17 \%)$ \\
Total & 15 & 11 & 6 & $32(26.66 \%)$ \\
& $69(57.50 \%)$ & $37(30.83 \%)$ & $14(11.67 \%)$ & 120 \\
\hline
\end{tabular}

$6^{\text {th }}$ Hypothesis:

\begin{tabular}{|c|c|c|c|}
\hline \multirow{2}{*}{$\begin{array}{l}\text { Learning Foreign } \\
\text { Language can } \\
\text { enhance job } \\
\text { opportunity in } \\
\text { MNCs }\end{array}$} & \multicolumn{2}{|c|}{ Gender } & \multirow[t]{2}{*}{ Total } \\
\hline & Female & Male & \\
\hline Agree & 29 & 42 & 71 (59.17\%) \\
\hline Disagree & 6 & 11 & 17 (14.17\%) \\
\hline Not Sure & 12 & 20 & $32(26.66 \%)$ \\
\hline Total & 47 (39.17\%) & 73 (60.83\%) & 120 \\
\hline
\end{tabular}

$7^{\text {th }}$ Hypothesis:

\begin{tabular}{|c|c|c|c|c|c|c|}
\hline \multirow{2}{*}{$\begin{array}{l}\text { Learning } \\
\text { Foreign } \\
\text { Language } \\
\text { can } \\
\text { enhance } \\
\text { job } \\
\text { opportunity } \\
\text { in MNCs }\end{array}$} & \multicolumn{5}{|c|}{ Present Academic / Professional Pursuit } & \multirow[t]{2}{*}{ Total } \\
\hline & $\begin{array}{c}\text { Higher } \\
\text { Secondary }\end{array}$ & $\begin{array}{c}\text { Graduation - } \\
\text { Academic }\end{array}$ & $\begin{array}{l}\text { Graduation - } \\
\text { Professional }\end{array}$ & $\begin{array}{c}\text { Post- } \\
\text { Graduation - } \\
\text { Academic }\end{array}$ & $\begin{array}{c}\text { Post- } \\
\text { Graduation - } \\
\text { Professional }\end{array}$ & \\
\hline Agree & 16 & 24 & 6 & 15 & 10 & 71 (59.17\%) \\
\hline Disagree & 0 & 5 & 6 & 2 & 4 & $17(14.17 \%)$ \\
\hline Not Sure & 1 & 15 & 5 & 5 & 6 & $32(26.66 \%)$ \\
\hline Total & 17 (14.17\%) & 44 (36.67\%) & 17 (14.17\%) & 22 (18.33\%) & 20 (16.66\%) & 120 \\
\hline
\end{tabular}


$8^{\text {th }}$ Hypothesis:

\begin{tabular}{lcccc}
\hline $\begin{array}{l}\text { Learning Foreign } \\
\text { Language can } \\
\text { enhance job }\end{array}$ & \multicolumn{3}{c}{ Career Objectives } & Total \\
\cline { 2 - 4 } $\begin{array}{l}\text { opportunity } \\
\text { as instructors } \\
\text { in Institutions }\end{array}$ & Service & Business & Not Sure & \\
$\begin{array}{l}\text { conducting foreign } \\
\text { language courses }\end{array}$ & & & & \\
\hline $\begin{array}{l}\text { Agree } \\
\text { Disagree }\end{array}$ & 33 & 18 & 6 & $57(47.50 \%)$ \\
$\begin{array}{l}\text { Not Sure } \\
\text { Total }\end{array}$ & 16 & 5 & 2 & $27(22.50 \%)$ \\
\hline
\end{tabular}

$9^{\text {th }}$ Hypothesis:

Learning Foreign Language can enhance job opportunity as instructors in Institutions conducting foreign language courses

\begin{tabular}{lccc}
\hline Agree & 26 & 31 & $57(47.50 \%)$ \\
Disagree & 6 & 21 & $27(22.50 \%)$ \\
Not Sure & 15 & 21 & $36(30.00 \%)$ \\
Total & $47(39.17 \%)$ & $73(60.83 \%)$ & 120 \\
\hline
\end{tabular}

\section{$10^{\text {th }}$ Hypothesis:}

\begin{tabular}{|c|c|c|c|c|c|c|}
\hline \multirow{2}{*}{$\begin{array}{l}\text { Learning } \\
\text { Foreign } \\
\text { Language can } \\
\text { enhance job } \\
\text { opportunity } \\
\text { as instructors } \\
\text { in institutions } \\
\text { conducting } \\
\text { foreign } \\
\text { languaage } \\
\text { courses }\end{array}$} & \multicolumn{5}{|c|}{ Present Academic/Professional Pursuit } & \multirow[t]{2}{*}{ Total } \\
\hline & $\begin{array}{c}\text { Higher } \\
\text { Secondary }\end{array}$ & $\begin{array}{c}\text { Graduation - } \\
\text { Academic }\end{array}$ & $\begin{array}{l}\text { Graduation - } \\
\text { Professional }\end{array}$ & $\begin{array}{c}\text { Post- } \\
\text { Graduation - } \\
\text { Academic }\end{array}$ & $\begin{array}{l}\text { Post- } \\
\text { Graduation - } \\
\text { Professional }\end{array}$ & \\
\hline Agree & 7 & 23 & 5 & 12 & 10 & $\begin{array}{c}57 \\
(47.50 \%)\end{array}$ \\
\hline Disagree & 6 & 5 & 6 & 4 & 6 & $\begin{array}{c}27 \\
(22.50 \%)\end{array}$ \\
\hline Not Sure & 4 & 16 & 6 & 6 & 4 & $\begin{array}{c}36 \\
(30.00 \%)\end{array}$ \\
\hline Total & $\begin{array}{c}17 \\
(14.17 \%)\end{array}$ & $\begin{array}{c}44 \\
(36.67 \%)\end{array}$ & $\begin{array}{c}17 \\
(14.17 \%)\end{array}$ & $\begin{array}{c}22 \\
(18.33 \%)\end{array}$ & $\begin{array}{c}20 \\
(16.66 \%)\end{array}$ & 120 \\
\hline
\end{tabular}

$11^{\text {th }}$ Hypothesis:

\begin{tabular}{|c|c|c|c|c|}
\hline \multirow{2}{*}{$\begin{array}{l}\text { Learning Foreign } \\
\text { Language } \\
\text { can enhance } \\
\text { overseas business } \\
\text { opportunities }\end{array}$} & \multicolumn{3}{|c|}{ Career Objectives } & \multirow[t]{2}{*}{ Total } \\
\hline & Service & Business & Not Sure & \\
\hline Agree & 49 & 28 & 7 & $84(70.00 \%)$ \\
\hline Disagree & 9 & 1 & 4 & 14 (11.67\%) \\
\hline Not Sure & 11 & 8 & 3 & $22(18.33 \%)$ \\
\hline Total & 69 (57.50\%) & 37 (30.83\%) & 14 (11.67\%) & 120 \\
\hline
\end{tabular}

$12^{\text {th }}$ Hypothesis:

\begin{tabular}{lccc}
\hline \multirow{2}{*}{$\begin{array}{l}\text { Learning Foreign Language can } \\
\text { enhance overseas business }\end{array}$} & \multicolumn{2}{c}{ Gender } & Total \\
\cline { 2 - 3 } opportunities courses & Female & Male & \\
\hline Agree & 35 & 49 & $84(70.00 \%)$ \\
Disagree & 4 & 10 & $14(11.67 \%)$ \\
Not Sure & 8 & 14 & $22(18.33 \%)$ \\
Total & $47(39.17 \%)$ & $73(60.83 \%)$ & 120 \\
\hline
\end{tabular}

$13^{\text {th }}$ Hypothesis:

\begin{tabular}{|c|c|c|c|c|c|c|}
\hline \multirow{2}{*}{$\begin{array}{l}\text { Learning } \\
\text { Foreign } \\
\text { Language } \\
\text { can enhance } \\
\text { overseas } \\
\text { business } \\
\text { opportunities } \\
\text { courses }\end{array}$} & \multicolumn{5}{|c|}{ Present Academic / Professional Pursuit } & \multirow[t]{2}{*}{ Total } \\
\hline & $\begin{array}{c}\text { Higher } \\
\text { Secondary }\end{array}$ & $\begin{array}{l}\text { Graduation - } \\
\text { Academic }\end{array}$ & $\begin{array}{l}\text { Graduation - } \\
\text { Professional }\end{array}$ & $\begin{array}{c}\text { Post- } \\
\text { Graduation - } \\
\text { Academic }\end{array}$ & $\begin{array}{c}\text { Post- } \\
\text { Graduation - } \\
\text { Professional }\end{array}$ & \\
\hline Agree & 13 & 31 & 7 & 19 & 14 & $\begin{array}{c}84 \\
(70.00 \%)\end{array}$ \\
\hline Disagree & 0 & 4 & 6 & 1 & 3 & $\begin{array}{c}14 \\
(11.67 \%)\end{array}$ \\
\hline Not Sure & 4 & 9 & 4 & 2 & 3 & $\begin{array}{c}22 \\
(18.33 \%)\end{array}$ \\
\hline Total & $\begin{array}{c}17 \\
(14.17 \%)\end{array}$ & $\begin{array}{c}44 \\
(36.67 \%)\end{array}$ & $\begin{array}{c}17 \\
(14.17 \%)\end{array}$ & $\begin{array}{c}22 \\
(18.33 \%)\end{array}$ & $\begin{array}{c}20 \\
(16.66 \%)\end{array}$ & 120 \\
\hline
\end{tabular}

$14^{\text {th }}$ Hypothesis:

\begin{tabular}{|c|c|c|c|c|}
\hline \multirow{2}{*}{$\begin{array}{l}\text { Learning Foreign } \\
\text { Language can } \\
\text { enhance self- } \\
\text { employment } \\
\text { opportunity as } \\
\text { interpreters }\end{array}$} & \multicolumn{3}{|c|}{ Career Objectives } & \multirow[t]{2}{*}{ Total } \\
\hline & Service & Business & Not Sure & \\
\hline Agree & 42 & 25 & 6 & $73(60.83 \%)$ \\
\hline Disagree & 15 & 2 & 3 & $20(16.67 \%)$ \\
\hline Not Sure & 12 & 10 & 5 & $27(22.50 \%)$ \\
\hline Total & 69 (57.50\%) & 37 (30.83\%) & $14(11.67 \%)$ & 120 \\
\hline
\end{tabular}

$15^{\text {th }}$ Hypothesis:

\begin{tabular}{|c|c|c|c|c|c|c|}
\hline \multirow{2}{*}{\multicolumn{2}{|c|}{$\begin{array}{l}\text { Learning Foreign } \\
\text { Language can } \\
\text { enhance self- } \\
\text { employment } \\
\text { opportunity as } \\
\text { interpreters }\end{array}$}} & \multicolumn{3}{|c|}{ Gender } & \multirow{2}{*}{\multicolumn{2}{|c|}{ Total }} \\
\hline & & \multicolumn{2}{|c|}{ Female } & Male & & \\
\hline \multicolumn{2}{|c|}{$\begin{array}{l}\text { Agree } \\
\text { Disagree } \\
\text { Not Sure } \\
\text { Total } \\
\end{array}$} & \multicolumn{2}{|c|}{$\begin{array}{c}31 \\
8 \\
8 \\
47(39.17 \%)\end{array}$} & $\begin{array}{c}42 \\
12 \\
19 \\
73(60.83 \%)\end{array}$ & \multicolumn{2}{|c|}{$\begin{array}{c}73(60.83 \%) \\
20(16.67 \%) \\
27(22.50 \%) \\
120\end{array}$} \\
\hline \multicolumn{7}{|c|}{$16^{\text {th }}$ Hypothesis: } \\
\hline \multirow{2}{*}{$\begin{array}{l}\text { Learning } \\
\text { Foreign } \\
\text { Language can } \\
\text { enhance self- } \\
\text { employment } \\
\text { opportunity } \\
\text { as interpreters } \\
\end{array}$} & \multicolumn{5}{|c|}{ Present Academic / Professional Pursuit } & \multirow[t]{2}{*}{ Total } \\
\hline & $\begin{array}{l}\text { Higher } \\
\text { Secondary }\end{array}$ & $\begin{array}{c}\text { Graduation - } \\
\text { Academic }\end{array}$ & $\begin{array}{l}\text { Graduation - } \\
\text { Professional }\end{array}$ & $\begin{array}{c}\text { Post- } \\
\text { Graduation - } \\
\text { Academic }\end{array}$ & $\begin{array}{c}\text { Post- } \\
\text { Graduation - } \\
\text { Professional }\end{array}$ & \\
\hline Agree & 12 & 24 & 8 & 15 & 14 & $\begin{array}{c}73 \\
(60.83 \%)\end{array}$ \\
\hline Disagree & 3 & 9 & 5 & 1 & 2 & $\begin{array}{l}20 \\
(16.67 \%)\end{array}$ \\
\hline Not Sure & 2 & 11 & 4 & 6 & 4 & $\begin{array}{c}27 \\
(22.50 \%)\end{array}$ \\
\hline Total & $\begin{array}{c}17 \\
(14.17 \%)\end{array}$ & $\begin{array}{c}44 \\
(36.67 \%)\end{array}$ & $\begin{array}{c}17 \\
(14.17 \%)\end{array}$ & $\begin{array}{c}22 \\
(18.33 \%)\end{array}$ & $\begin{array}{c}20 \\
(16.66 \%)\end{array}$ & 120 \\
\hline
\end{tabular}

\subsection{Synopsis of the Above Observations}

\begin{tabular}{lcccc}
\hline Attributes & \multicolumn{3}{c}{ Attitude with corresponding percentage of } \\
& \multicolumn{4}{c}{ respondents } \\
\hline Intention to learn foreign languages & Willing & Unwilling & Not Sure & Total \\
& $67.50 \%$ & $15.83 \%$ & $16.67 \%$ & $100 \%$ \\
Proficiency in foreign languages can & Agree & Disagree & Not Sure & Total \\
enhance job opportunities in MNCs & $59.17 \%$ & $14.17 \%$ & $26.66 \%$ & $100 \%$
\end{tabular}


Proficiency in foreign languages can enhance job opportunities as instructors in institutions conducting foreign language courses

Proficiency in foreign languages can enhance overseas business opportunities

Proficiency in foreign languages can enhance self-employment opportunity as interpreters
Agree Disagree Not Sure Total $47.50 \% \quad 22.50 \% \quad 30.00 \% \quad 100 \%$ Agree Disagree Not Sure Total $70.00 \% \quad 11.67 \% \quad 18.33 \% \quad 100 \%$ Agree Disagree Not Sure Total $60.83 \% \quad 16.67 \% \quad 22.50 \% \quad 100 \%$

It transpires from the above synopsis that majority of the respondents are willing to learn foreign languages and are aware of the prospects of gaining proficiency in foreign languages. However, only in the case of career opportunity as instructors in institutions conducting courses in foreign languages, it has been observed that slightly less than $50 \%$ of the respondents exhibited positive attitude. This is attributable to the low number of such institutions in Kolkata and suburbs and the resultant low potential of job opportunities as instructors in such institutions.

\subsection{Findings of Hypotheses Testing:}

\begin{tabular}{|c|c|c|c|c|c|}
\hline \multirow[b]{2}{*}{ Hypotheses } & \multirow[b]{2}{*}{$\begin{array}{c}\chi^{2} \\
\text { Calculated }\end{array}$} & \multicolumn{2}{|c|}{$\begin{array}{c}\text { At } 5 \% \text { Level of } \\
\text { Significance }\end{array}$} & \multicolumn{2}{|c|}{$\begin{array}{c}\text { At } 1 \% \text { Level of } \\
\text { Significance }\end{array}$} \\
\hline & & $\begin{array}{c}\chi^{2} \\
\text { Tabulated }\end{array}$ & Decision & $\begin{array}{c}\chi^{2} \\
\text { Tabulated }\end{array}$ & Decision \\
\hline $1^{\text {st }}$ & $3.57 \mathrm{DF}=4$ & 9.488 & $\mathrm{H}_{0}$ Accepted & 13.277 & $\mathrm{H}_{0}$ Accepted \\
\hline $2^{\text {nd }}$ & $1.02 \mathrm{DF}=2$ & 5.991 & $\mathrm{H}_{0}$ Accepted & 9.210 & $\mathrm{H}_{0}$ Accepted \\
\hline $3^{\text {rd }}$ & $6.24 \mathrm{DF}=8$ & 15.507 & $\mathrm{H}_{0}$ Accepted & 20.090 & $\mathrm{H}_{0}$ Accepted \\
\hline $4^{\text {th }}$ & $5.30 \mathrm{DF}=4$ & 9.488 & $\mathrm{H}_{0}$ Accepted & 13.277 & $\mathrm{H}_{0}$ Accepted \\
\hline $5^{\text {th }}$ & $4.32 \mathrm{DF}=4$ & 9.488 & $\mathrm{H}_{0}$ Accepted & 13.277 & $\mathrm{H}_{0}$ Accepted \\
\hline $6^{\text {th }}$ & $0.23 \mathrm{DF}=2$ & 5.991 & $\mathrm{H}_{0}$ Accepted & 9.210 & $\mathrm{H}_{0}$ Accepted \\
\hline $7^{\text {th }}$ & $18.70 \mathrm{DF}=8$ & 15.507 & $\mathrm{H}_{0}$ Rejected & 20.090 & $\mathrm{H}_{0}$ Accepted \\
\hline $8^{\text {th }}$ & $5.71 \mathrm{DF}=4$ & 9.488 & $\mathrm{H}_{0}$ Accepted & 13.277 & $\mathrm{H}_{0}$ Accepted \\
\hline $9^{\text {th }}$ & $4.34 \mathrm{DF}=2$ & 5.991 & $\mathrm{H}_{0}$ Accepted & 9.210 & $\mathrm{H}_{0}$ Accepted \\
\hline $10^{\text {th }}$ & 9.07 DF $=8$ & 15.507 & $\mathrm{H}_{0}$ Accepted & 20.090 & $\mathrm{H}_{0}$ Accepted \\
\hline $11^{\text {th }}$ & $7.58 \mathrm{DF}=4$ & 9.488 & $\mathrm{H}_{0}$ Accepted & 13.277 & $\mathrm{H}_{0}$ Accepted \\
\hline $12^{\text {th }}$ & $0.95 \mathrm{DF}=2$ & 5.991 & $\mathrm{H}_{0}$ Accepted & 9.210 & $\mathrm{H}_{0}$ Accepted \\
\hline $13^{\text {th }}$ & $16.23 \mathrm{DF}=8$ & 15.507 & $\mathrm{H}_{0}$ Rejected & 20.090 & $\mathrm{H}_{0}$ Accepted \\
\hline $14^{\text {th }}$ & $7.31 \mathrm{DF}=4$ & 9.488 & $\mathrm{H}_{0}$ Accepted & 13.277 & $\mathrm{H}_{0}$ Accepted \\
\hline $15^{\text {th }}$ & $1.37 \mathrm{DF}=2$ & 5.991 & $\mathrm{H}_{0}$ Accepted & 9.210 & $\mathrm{H}_{0}$ Accepted \\
\hline $16^{\text {th }}$ & $7.35 \mathrm{DF}=8$ & 15.507 & $\mathrm{H}_{0}$ Accepted & 20.090 & $\mathrm{H}_{0}$ Accepted \\
\hline
\end{tabular}

6.4 Observations: All the hypotheses have been accepted at both $5 \%$ \& $1 \%$ levels of significance with the exception of hypotheses numbers 7 and 13 which have been rejected at 5\% level of significance. This shows that there is no significant association between the attitude

of the respondents towards foreign languages and their demographic attributes.

\section{The Way Forward}

The findings and analysis thereof portray a favorable situation where majority of the students exhibited awareness about the prospects of learning foreign languages and indicated their intentions to learn foreign languages. The unwilling students and those who are undecided in the matter need to be counseled appropriately.

Educational institutions conducting academic and professional courses should arrange for periodic seminars where delegates from industries, foreign consulates as well as institutions conducting courses in foreign languages would apprise students about the opportunities of learning foreign languages and motivate them to gain multi-linguistic proficiency. The absence of association with the attitude of students and their demographic attributes, as proven by the hypotheses testing mentioned above makes the process easier as the motivating process need not be a differentiated approach for different groups. A uniform approach would be just as effective.

Working executives having exposure to foreign business deals should be encouraged by their employers to learn foreign languages.

\section{Conclusion}

The demographic profile of India has a unique characteristic. A large portion of our population is in the young age groups who have a long career path ahead of them. If this work force gains multi-linguistic proficiency, then the quality of human capital in India would get enhanced. As a sequel, India would become the preferred location for foreign MNCs which would be a boon to our national economy. Moreover, Indian workers would find enhanced employment opportunities abroad.

However, there remains scope of further research in the field considering more attributes and larger samples from different places of the country to validate the findings of this study. 


\section{Annexure}

\section{QUESTIONNAIRE}

1. What is your career objective? [Please tick only one option] $\square$ Service $\square$ Business/Independent Profession $\square$ Not Sure

2. Do you feel that doing other short term courses is essential for enhancing job/business prospects? [Please tick only one option]

$\square$ Agree $\square$ Not Sure $\square$ Do not Agree

3. Please award marks (out of 10) to each of the following short term courses:

Computers languages $\square$ Spoken English $\square \quad$ Learning other Foreign Languages $\square$

4. Please award marks (out of 10) to the following modes of learning spoken English:

Joining a spoken English course $\square$ Read English dailies/journals regularly $\square$

Watch English TV Channels/Movies $\square \quad$ Converse in English with others $\square$

5. Do you feel that expertise in spoken English

is enough as far as communication skills in industry is required? [Please tick only one option]

$\square$ Yes $\square$ Not Sure $\square$ No

6. How can the skill in foreign languages help you in your career: [Please tick only one option]

It enhances my chance in getting a job in MNCs

Agree $\square \quad$ Not Sure $\square \quad$ Disagree $\square$

I can be a teacher in institutes teaching foreign languages

Agree $\square \quad$ Not Sure $\square$ Disagree $\square$

Enhances business opportunities as I can communicate

with foreign customers

Agree $\square \quad$ Not Sure $\square$ Disagree $\square$

I can operate as a free lance interpreter

Agree $\square \quad$ Not Sure $\square \quad$ Disagree $\square$

7. Please award Marks (out of 10) to the following foreign languages as enhancers of employability/ business prospects:

French $\square$ Spanish $\square$ German $\square$ Chinese $\square$ Japanese $\square$ Russian $\square$

8. Do you wish to learn a foreign language? [Please tick only one option]

$\square$ Yes $\square$ Not Sure $\square$ No

9. Something more about you: [Please tick only one option against each question]

a. You are a student of: $\square$ HS $\square$ Polytechnic $\square$ BBA $\square$ B.A. $\square$ B.Sc. $\square \quad$ B.Com B.E./B.Tech/B.Pharm

b. You are: $\square$ Male $\square$ Female

c. Your Domicile: $\square$ City $\square$ Urban Periphery $\square$ Rural

d. Your medium of education: $\square$ English $\square$ Bengali $\square$ Hindi $\square$ Urdu $\square$ Others

e. Your mother tongue: $\square$ Bengali $\square$ Hindi $\square$ Urdu $\square$ Others 


\section{References}

AACSB International. (2011). Globalisation of Management Education: Changing International Structures, Adaptive Strategies and the Impact on Institutions. Report of the AACSB International Globalization of Management Education Task Force.

Ansari , H. (1995). Managing Cultural Diversity at work. Kogan Page Ltd.

Bhattacharya, D. K. (2010). Cross Cultural Management Texts and Cases. New Delhi: PHI Learning Pvt. Ltd. Bhattacharya, R. (2012). Managing Cultural Diversity. B R Publishing Corporation.

De Bono, S., van Der Heijden, B. (2011). Managing Cultural Diversity. Meyer \& Meyer Fachvrlag Und Buchhandel GmBH.

Dogra, D. (2009). Towards managing Diversity: Cultural Aspects of Business Environment. Reference Press.

Edwards V. (2011). Globalization and Multilingualism: The Case of UK. Intercultural Communication Studies, 20(1), 27-35.

Gupta, N. L. (1998). Cross Cultural Communication: Global Perspectives. Concept Publishing.

Hamdorf, D. (2006). Towards managing Diversity - Cultural Aspects of Conflict Management in International Business Environments. VDM Verlag Dr. Muller.

Levine, D. M., Stephan, D. F., Krehbiel, T. S., \& Berenson, M. L. (2010). Statistics for Managers (5th ed.). PHI Learning Pvt. Ltd.

Madhavan, S. (2011). Cross Cultural Management. Oxford University Press.
Maude, B. (2011). Managing Cross-Cultural Communication: Principles and Practice. Palgrave MacMillan.

NEA Research. (2007). The Benefits of Second Language Study. Regarding World language Education.

Norales, F. O. (2006). Cross-Cultural Communication: Concepts, Cases \& Challenges. Cambria Press.

\section{About the Author}

Rajib Bhattacharya graduated in Commerce and did his masters and M.Phil in management. He is also a qualified Cost \& Management Accountant besides having a post graduate diploma in Personnel Management \& Industrial Relations. Currently he is doing his Ph.D in Management. He has over ten years of industrial experience in various sectors including consultancy, manufacturing, agro-based and banking in the areas of Accounting, Cost Control, Fund Management and Institutional Credit. He is currently associated with Budge Budge Institute of Technology in Kolkata as an Assistant Professor for Financial and Strategic Management. He is a member of The Institute of Cost and Works Accountant of India, All India Management Association and Operational Research Society of India. He has authored 16 papers which have been presented/published in different international conferences/journals. His research interests include small and medium sector units and multi-variate statistical analysis and modeling. He can be reached at bh.rajib@gmail.com

Sharmila Maity is a student in the final semester of MBA program of Sikkim Manipal University, Gangtok, Sikkim. 